\title{
Seasonal Energy Dynamics of the Alewife in Southeastern Lake Michigan
}

\author{
Loren E. Flath and James S. Diana ${ }^{1}$ \\ School of Natural Resources and Great Lakes Research Division \\ University of Michigan, Ann Arbor, Michigan 48109
}

\begin{abstract}
Alewives Alosa pseudoharengus collected in southeastern Lake Michigan from October 1979 to October 1981 were analyzed for caloric content, lipid, and lean dry (lipid-free) weight. The relative seasonal change in energy density (kcal/g wet weight) was similar in adults and immature fish, although immatures generally had lower caloric equivalents. Seasonal lows in caloric equivalents occurred in April for immature fish in their first year $(1.03 \mathrm{kcal} / \mathrm{g})$ and in June for adults $(1.30$ $\mathrm{kcal} / \mathrm{g})$, whereas maxima were found in October for all age groups $(2.30 \mathrm{kcal} / \mathrm{g})$. Somatic energy losses during winter were $27 \%$ for adult females and $23 \%$ for males; spawning-related losses were higher ( $37 \%$ and $45 \%$, respectively). Percent lipid followed the same seasonal trends as caloric equivalents with maxima in the fall (17\% wet weight) and minima in late spring-summer (3-5\%). Approximately $80 \%$ of gonad growth and maturation took place from April to late May when feeding was at a minimum. Energy requirements for gonad growth apparently came mainly from body lipid, although body protein also was used. Most body growth occurred in the fall. Seasonal increases and declines in growth were related to food availability, temperature, and spawning. Annual die-offs correspond with seasonal energy lows, indicating that mortalities may be induced by insufficient feeding the previous fall.
\end{abstract}

Received July 27, 1983

Accepted February 27, 1985

After their establishment in the Great Lakes, alewives Alosa pseudoharengus emerged as a Great Lakes scourge because of annual die-offs that fouled beaches and fishing gear and clogged water intake systems. Such problems occurred with some seasonal regularity (mainly in the spring), particularly in lakes Ontario (Pritchard 1929; Graham 1956) and Michigan (Smith 1968).

Alewives are now an important component of the Lake Michigan ecosystem. Exotic salmonids were introduced to Lake Michigan through an intense stocking program that began in the mid 1960 s and presently continues. The success of the salmon program is based on effective control of sea lampreys Petromyzon marinus and abundant forage provided by alewives. Native lake trout Salvelinus namaycush make up about $20 \%$ of Lake Michigan's salmonid population, and all species together consume about one-third of the annual production of alewives each year (Stewart et al. 1981). Understanding production of alewives is necessary in order to evaluate salmonidalewife interactions and to develop management strategies (Stewart et al. 1981).

Several factors influence production and en-

\footnotetext{
${ }^{1}$ Person to whom reprint requests should be sent.
}

ergy use by alewives. One of these is temperature, which, in turn, strongly influences food availability and is tied closely to the annual reproductive cycle (Williams 1966; Wootton 1979). Gonad growth and maturation, two of the most energy-demanding processes in a mature individual, can occur with or at the expense of somatic tissue growth (Shul'man 1974; Woodhead 1979). The relative cost of reproduction, measured in percent somatic energy loss during the spawning period, varies widely in fish (e.g., 13\% for northern pike Esox lucius [Diana and Mackay 1979] to $85 \%$ for chinook salmon Oncorhynchus tshawytscha [Glebe and Leggett 1981]).

The purpose of this study was to evaluate the seasonal energy dynamics of gonad and somatic tissue for each sex and age group of alewives in southeastern Lake Michigan. These evaluations were refined further by examination of trends in lean dry weight and lipid. Finally, implications of the trends for models of salmon-alewife interactions were assessed.

\section{Methods \\ Field Sampling}

Alewives were collected from southeastern Lake Michigan near Benton Harbor, Saugatuck, and Grand Haven, Michigan, from October 1979 
to October 1981. November and April samples were taken in trawls fished by the $\mathrm{R} / \mathrm{V}$ Cisco (U.S. Fish and Wildlife Service) in deep water off Saugatuck. All other samples were obtained in nearshore areas (depths, 3-20 m) with seines, experimental gill nets, and an otter trawl. Samples were collected nearly every month from April to October during the study. No winter collections were made. The fish were sorted into size groups, frozen, and stored at $-20^{\circ} \mathrm{C}$ until analyzed.

\section{Growth Analysis}

Total and standard lengths were measured to $1 \mathrm{~mm}$, total wet weight to $0.01 \mathrm{~g}$, and gonad wet weight to $0.001 \mathrm{~g}$. Sex and gonad condition were determined visually. Scales were removed from the area between the lateral line and insertion of the dorsal fin or, if not available there, from the caudal peduncle. All fish were aged individually after the method of Rothschild (1963). Fish were assumed to enter the next higher age group on 1 January. Age-5 and older fish could not be separated accurately into age groups and were therefore excluded from analysis.

Somatic samples were prepared by removal of gonads and stomach contents, and each fish larger than $10 \mathrm{~g}$ was homogenized in a food processor. Approximately one-half of this homogenate was frozen. The remaining portion of the body and the entire gonads were weighed to $0.001 \mathrm{~g}$ and dried to constant weight at $50^{\circ} \mathrm{C}$ ( 5 to 7 days). Smaller fish $(<10 \mathrm{~g})$ were dried whole. The tissue was then reweighed to $0.001 \mathrm{~g}$, ground in a coffee mill, and stored in capped vials at $-20^{\circ} \mathrm{C}$.

\section{Lipid Analysis}

Approximately $1 \mathrm{~g}$ of tissue (weighed to 0.0001 g) was extracted for $12-16 \mathrm{~h}$ with a $2: 1$ chloroform : methanol solvent in a soxhlet apparatus (Folch et al. 1957; Craig 1977). Following extraction of lipids, samples were left overnight to air dry and then dried to constant weight in a desiccator $(2 \mathrm{~h})$. Subsequent reweighing determined lipid-free weight of the sample, which was used to calculate the total lipid residue (sample dry weight minus lipid-free weight). An empty filter paper (blank) was also run along with the three samples in each soxhlet. No significant change in weight was found in the blanks.

To determine the nonlipid component (comprising primarily proteins that dissolved in the solvent) of the total lipid residue, 15 samples were extracted, and the resulting solvent was subsampled. One-half was poured into a preweighed drying dish and the other half was washed with a polar solvent (Folch et al. 1957) and left overnight in a separatory funnel; the lipid-containing portion then was poured into another preweighed drying dish. Solvent was evaporated from both dishes and each was weighed to 0.001 g. There was no significant difference (paired $t$-test; $P=0.05$ ) between the weight of the unwashed residue for each sample and the weight of the total lipid residue. The weight of the washed residue was assumed to be the total lipid component, and was subtracted from the total residue to find the nonlipid component. These data were best described by the equation $\left(r^{2}=0.89\right)$

$$
Y=e^{-15.6} X^{5.834}
$$

where $Y$ is the weight of the nonlipid component (mg) and $X$ the total weight of the residue (mg). The weight of a particular residue was substituted into this equation, and the nonlipid component was first calculated and then subtracted from the total lipid residue $(X)$ to determine the actual lipid weight for each sample.

\section{Caloric Analysis}

Calorimetry was conducted with a Phillipson Microbomb calorimeter (Paine 1971). Ten-milligram samples of gonad tissue were used, and duplicate runs of 12 samples produced a mean error of $2.7 \pm 0.2 \%$ (mean $\pm \mathrm{SD}$ ). After this, only one determination was done for each sample. Somatic analysis was more variable, so sample size was increased to $40 \mathrm{mg}$, and a Wiley mill was used to grind somatic samples. Following these changes, duplicate runs of 10 somatic tissue samples were well within $5 \%$ of each other $(3.3 \pm$ $0.03 \%$ ). All subsequent somatic tissue samples were analyzed without replication.

\section{Statistical Analysis}

All fish were analyzed individually, and all data expressed as means were derived from individual observations. Total body energy was calculated as the product of the fish's wet body weight, proportion of dry matter (dry weight/wet weight), and $\mathrm{kcal} / \mathrm{g}$ dry weight. Total body lipid was calculated in the same manner, percent lipid being substituted for $\mathrm{kcal} / \mathrm{g}$. Lean dry body weight was considered total dry weight minus the total body lipid. Somatic production was calculated as the difference in total body energy from the annual 

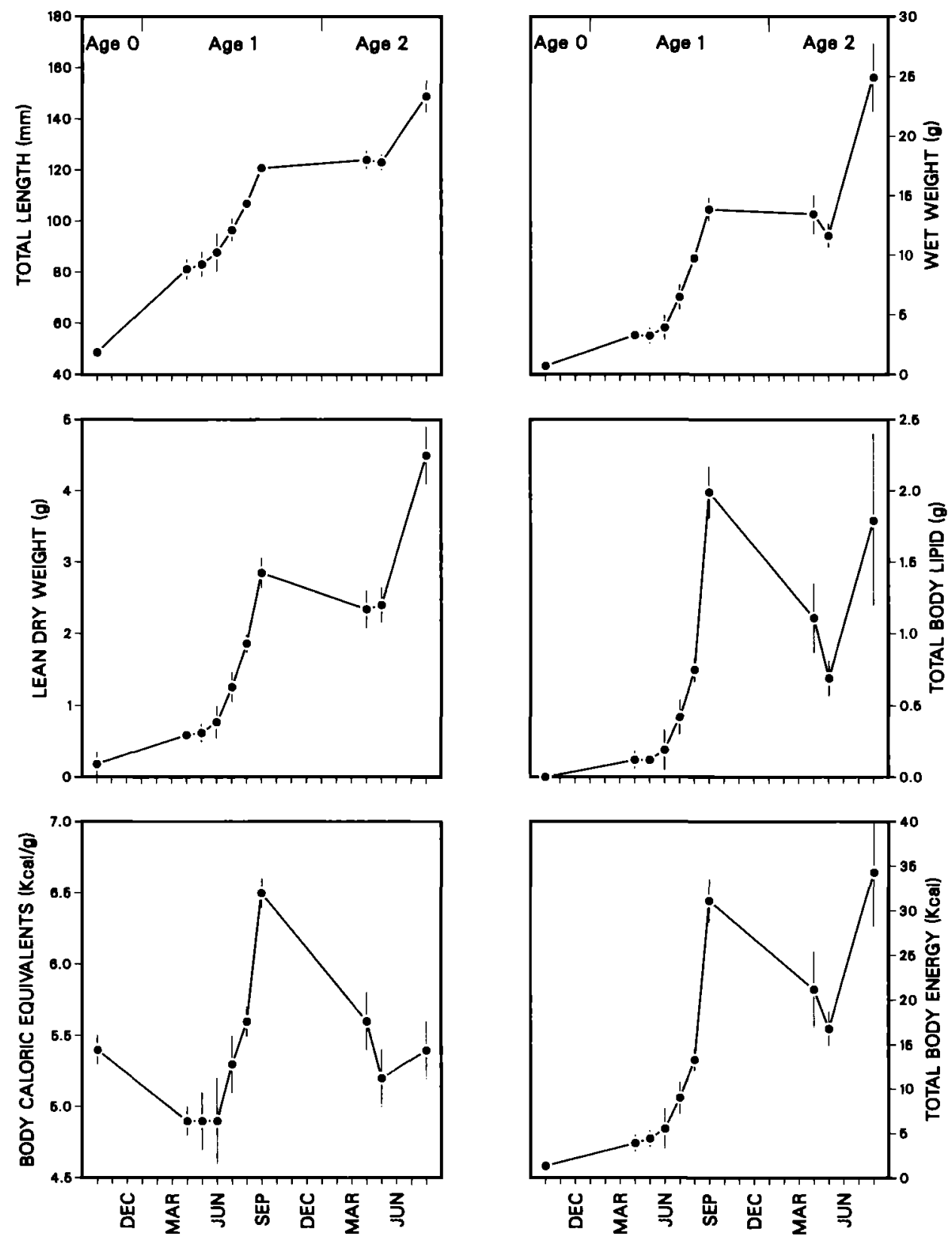

\section{MONTH}

FIGURE 1.-Seasonal changes in mean ( $\pm 2 S E$ ) total length, wet weight, lean dry weight, total body lipid, body caloric equivalents, and total body energy content of age-0-2 alewives collected from southeastern Lake Michigan. These data represent a chronological sequence of changes from the first observation of young of the year (October) to the approximate period of first sexual maturation. Data with nonoverlapping vertical bars are significantly different (Scheffe test; $\mathbf{P}=0.05$ ). 


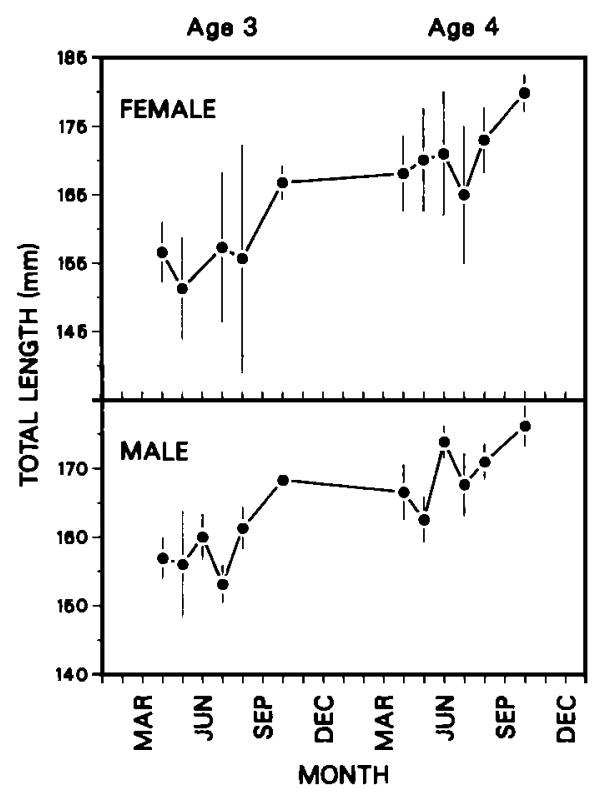

FIGURE 2. - Seasonal changes in mean ( $\pm 2 S E$ ) total length of age- 3 and -4 alewives.

minimum (postspawning) to the maximum value (October).

Somatic depletion was determined for the overwintering and spawning periods. The difference between maximum energy levels in October and minimum levels the following summer was considered total depletion. Overwintering depletion was the difference between October and April energy levels expressed as a percentage of the October level. Similarly, spawning depletion was the difference between the lowest postspawning value (near July) and the highest prespawning level (near April) expressed as a percentage of the prespawning level.

Data were analyzed with the Michigan Interactive Data Analysis System at The University of Michigan (Fox and Guire 1976). Any differences in the seasonal, age, or sex related data were determined by analysis of variance and Scheffé procedure $(P=0.05$; Miller 1966). Additional relationships among variables were developed with simple linear- and multiple-regression techniques.

\section{Results \\ Immature Fish}

Monthly mean values for body weight, total body lipid, and lean dry body weight did not

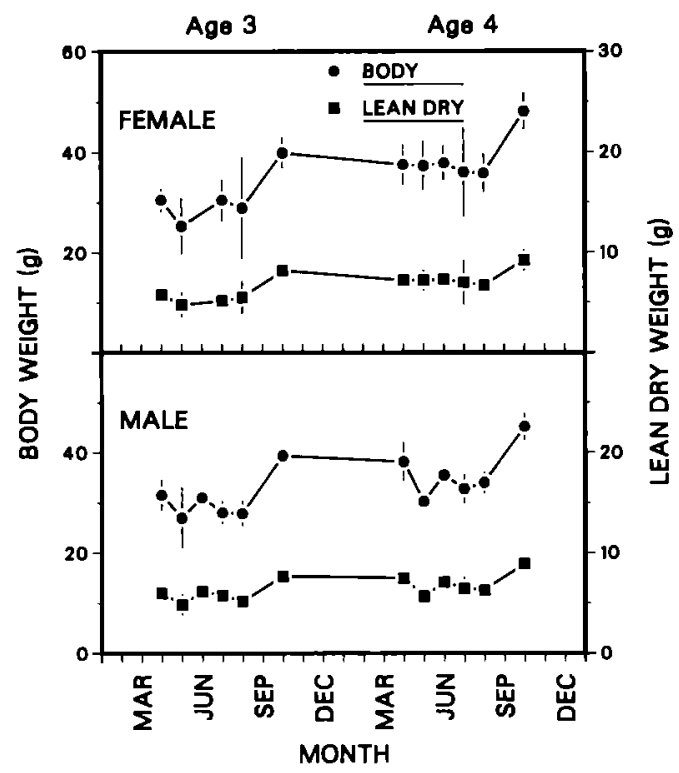

FIGURE 3. - Seasonal changes in mean ( $\pm 2 S E$ ) body weight and lean dry weight of adult alewives.

differ significantly among years. Therefore, data from a given month were combined across years. Young-of-year fish were first collected in October at an average total length of $48.5 \mathrm{~mm}$ and wet weight of $0.71 \mathrm{~g}$ (Fig. 1). Overwinter results are tenuous owing to difficulties in obtaining a representative sample of age- 0 fish during this period. Growth for age-1 fish (as indicated by lean dry weight, total body energy, and total body lipid) increased beginning in April and continued throughout all subsequent months until the following winter (Fig. 1). The greatest growth occurred between August and September. There was no significant change in total length and weight during the second winter. In spite of this, lean dry body weight, total body energy, and body lipid decreased significantly over the second winter (Fig. 1).

Percent lipid showed a similar pattern to body lipid, but did not fluctuate as widely. In contrast to total lipid, percent lipid decreased over the first winter from $7.63 \%$ to $5.05 \%$. A strong inverse relationship existed between percent water and percent lipid. In general, the combination of percent lipid and percent water accounted for $80 \%$ of fish wet weight. Fish weight could remain nearly stable while lipid and water fluctuated proportionally; this, in turn, would cause fluctuations in caloric content without a concomitant change in wet weight. 
TABLE 1.-Combined mean (SE) monthly values for percent water, percent lipid, and caloric equivalents for alewives from southeastern Lake Michigan.

\begin{tabular}{lccc}
\hline & & $\begin{array}{c}\text { Caloric } \\
\text { equivalent } \\
\text { (kcal/g } \\
\text { wet weight) }\end{array}$ \\
Month & Percent water & Percent lipid & \\
Apr & \multicolumn{3}{c}{ Males } \\
May & $78.7(0.6)$ & $12.2(0.5)$ & $6.04(0.07)$ \\
Jun & $75.7(0.4)$ & $8.0(0.8)$ & $5.48(0.11)$ \\
Jul & $74.2(1.3)$ & $4.6(0.4)$ & $5.05(0.05)$ \\
Aug & $75.6(0.7)$ & $5.1(0.7)$ & $5.44(0.09)$ \\
Oct & $64.2(0.9)$ & $16.3(0.6)$ & $5.17(0.11)$ \\
& & Females & $6.60(0.08)$ \\
Apr & $70.8(1.13)$ & $10.3(1.16)$ & $5.81(0.14)$ \\
May & $71.2(0.69)$ & $10.3(0.80)$ & $5.82(0.11)$ \\
Jun & $75.7(1.30)$ & $6.2(1.50)$ & $5.07(0.17)$ \\
Jul & $75.2(2.40)$ & $7.0(1.40)$ & $5.38(0.18)$ \\
Aug & $75.0(0.63)$ & $6.3(0.73)$ & $5.25(0.09)$ \\
Oct & $64.2(1.10)$ & $16.4(0.75)$ & $6.59(0.10)$ \\
\hline & & &
\end{tabular}

\section{Adults}

Adult females began a length increase in August that continued through October (Fig. 2). The increase was $11 \mathrm{~mm}$ for age- 3 and $7 \mathrm{~mm}$ for age- 4 females. Length of age- 3 and -4 males increased between May and June, decreased by July, then increased through October. No changes in length occurred during the winter.

Age-3 and -4 alewives of both sexes had significant increases in weight between August and October (Fig. 3). These groups also showed decreases in weight over the winter. Similarly, lean dry body weight increased in the fall, all ages of both sexes showing significant increases between August and October (Fig. 3). Lean dry body weight decreased over winter in both sexes but not significantly.

Monthly data for percent water, percent lipid, and caloric equivalents were combined by sex over the three age groups because there were no significant differences between ages. In both sexes, percent water increased significantly from April to June, dropped significantly from August to October, and then increased over the winter (Table 1). Males had higher relative water content than females in May and June, but there were no significant differences between the sexes during the other months.

Percent lipid and caloric equivalents showed parallel trends (Table 1). Both variables decreased significantly from April to June, increased from August to October, then declined

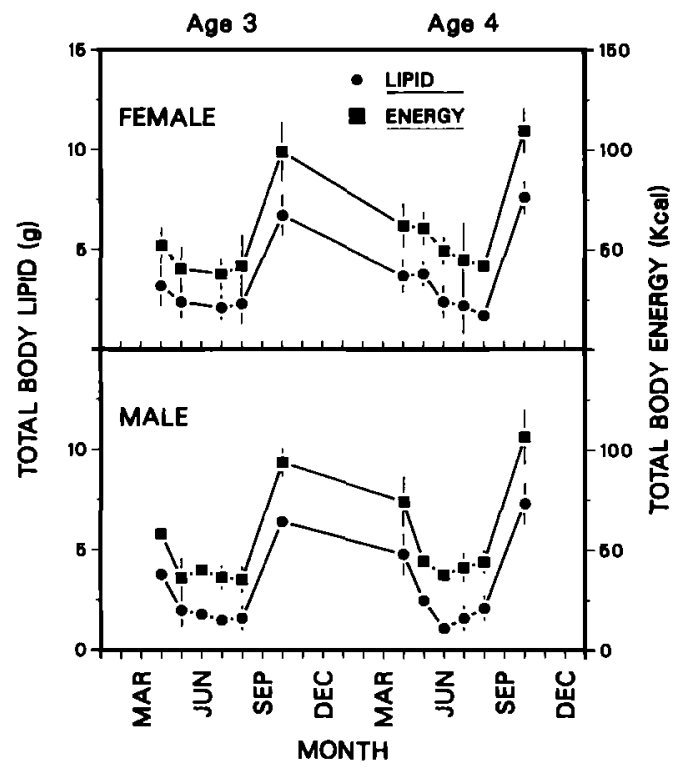

FIGURE 4. - Seasonal changes in mean ( $\pm 2 S E$ ) total body lipid and total body energy of adult alewives.

over the winter for both sexes. During May, June, and July, percent lipid in females was significantly greater than in males; at other times the sexes had similar levels. Caloric equivalents were also significantly higher for females than for males in May (Table 1).

Total body lipid showed changes similar to percent lipid, although differences did occur among ages (Fig. 4). Males and females of both age groups increased significantly in total body lipid between August and October and exhibited a significant decrease in total body lipid over the winter. In males, total body lipid was lowest in July for age-3 fish and in June for age-4 fish. Females had minimum levels in July $(2.1 \mathrm{~g})$ for age- 3 fish and in August for age- 4 fish. Maximum total body lipid for males and females occurred in October for both ages.

Both age groups of both adult sexes exhibited similar seasonal trends in total body calories (Fig. 4). The general pattern included maximum body energy in the late fall, steady depletion over the winter and through the spawning period (June or July), and subsequent accumulation throughout late summer and fall. Males and females had similar annual production: 58 and $69 \mathrm{kcals}$ for ages- 3 and - 4 males; 61 and 68 kcals for ages-3 and -4 females. No significant differences occurred between sexes. 
TABle 2. - Percent somatic depletion in adult alewives for overwintering and spawning periods.

\begin{tabular}{lcrc}
\hline & \multicolumn{2}{c}{ Age } & \\
\cline { 2 - 3 } Sex & 3 & 4 & Mean \\
\hline & \multicolumn{1}{c}{ Overwinter $($ Oct-Apr) } \\
Female & $29 \%$ & 37 & \\
Male & 25 & 21 & 27 \\
& Spawning $($ Apr-Jul) & \\
Female & 28 & 33 & 37 \\
Male & 39 & 49 & 45 \\
\hline
\end{tabular}

Somatic depletion was pronounced for the two major energy-demanding periods, overwintering and spawning (Table 2). Females, on the average, used more stored energy over winter than males. On the other hand, males used more somatic reserves during spawning than females.

Testicular caloric equivalents remained constant between October and April and dropped significantly between April and May (Table 3). There was a decrease from May to June when the fish were ripe. No change was noted in caloric equivalents between ripe testes in June and spent gonads in August. Females exhibited the opposite pattern in ovary caloric equivalents. A slight increase was noted between April and May and a significant increase occurred between May and June. Spent ovaries in August had significantly lower caloric equivalents than ripe ovaries in June.

There were significant increases in total gonad energy content between April and May in age-4 fish of both sexes (Fig. 5). Maximum gonad energy content occurred in June for age- 4 fish and in July for age- 3 alewives, while minimum values all occurred in August. Females exhibited within-month variation during spawning because of the presence of individuals with gonad conditions varying from ripe to spent. Ripe females accumulated about twice as much energy in their ovaries as males did in their testes.

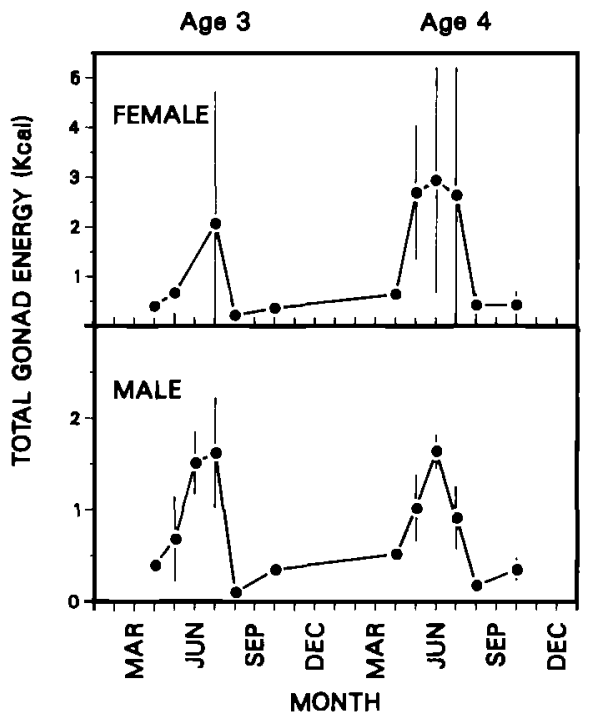

Figure 5.-Seasonal variation in mean ( $\pm 2 S E$ ) total gonad energy of adult alewives.

\section{Discussion}

Seasonal growth and lipid accumulation occurred almost exclusively from August to October in Lake Michigan alewives, corresponding with their major feeding period (Yeo 1978). Adult and immature fish in this study had nearly identical seasonal trends in energy accumulation and depletion, and these seasonal trends were similar to those of several other fish species (Iles 1974).

The inverse relationship between lipid and water, as well as the large seasonal fluxes in energy content of alewives, argue strongly for the inclusion of proximate composition data in bioenergetic models used to analyze salmon-alewife interactions. For example, Stewart et a1. (1981) used caloric data from Yeo (1978) to estimate annual alewife production. Data from the present study, which are more comprehensive for age groups and sexes, indicate potential errors of 10 $30 \%$ in the relationship between weight and en-

TABLE 3. - Mean (SE) dry-weight caloric equivalents ( $\mathrm{kcal} / \mathrm{g}$ ) of gonadal tissue for adult alewives. $1=$ undeveloped; $2=$ moderately developed $3=$ ripe; $5=$ spent. Data are combined by age.

\begin{tabular}{ccccc}
\hline & \multicolumn{4}{c}{ Gonad maturation index } \\
\cline { 2 - 5 } Sex & 1 & 2 & 3 & 5 \\
Oct-Apr & May & Jun & Aug \\
\hline Female & $4.95(0.07)$ & $5.00(0.05)$ & $5.31(0.07)$ & $4.76(0.07)$ \\
Male & $5.69(0.07)$ & $5.19(0.05)$ & $5.03(0.07)$ & $5.06(0.03)$ \\
\hline
\end{tabular}


ergy content of alewives in Yeo's (1978) study. Similarly, seasonal fluctuations in proximate composition are very important in estimating consumption of alewives by salmon. Lake Michigan salmonids would get the maximum return per bite during the fall. In terms of caloric contribution, one October adult provides the same energy as 1.6 adults of the same length consumed in June. Stewart et al. (1981) evaluated various salmonids in Lake Michigan for length of life and predatory impact on forage. Seasonal differences in timing of food consumption, as well as in alewife energy content, also should be considered in such assessments.

Lake Michigan alewives did not grow over the winter, which may be due to limited food availability or to an inability to feed at cold temperatures (Colby 1973). Several other spring-spawning fish (e.g., Clupea harengus, Wilkins 1967; Osmerus mordax, Foltz and Norden 1977) also fast over winter and into the spawning period and accomplish maximum growth during the postspawning season. Coastal alewives (Cooper 1961) and American shad Alosa sapidissima (Glebe and Leggett 1981) fast during spring freshwater migrations and resume feeding upon return to the sea.

Alewives used endogenous energy stores not only for maintenance during the winter, but also for gonad growth and maturation, the bulk of which was accomplished in the 2 months prior to spawning. The rapid loss of body lipid in the spring, concomitant with increased gonad weight, indicated that stored lipid and possibly limited feeding were the primary sources of energy. It is doubtful that much direct transfer of stored lipid from body to gonad took place during maturation, because only very small amounts of lipid are found in clupeid gonadal tissue (Lasker 1962; Kaitaranta and Ackman 1981). Females used more energy reserves during winter than males, which was probably due to egg production, larger size, and higher maintenance costs. Males used more energy reserves during spawning, indicating that spawning activity is more costly to male alewives. This has been shown for other species (Diana and Mackay 1979), and is probably due to a longer duration of spawning by male fish.

Although no protein determinations were attempted in this study, lean dry body weight (mainly protein, carbohydrate, and ash) was considered a good representation of protein. Carbohydrate makes up a negligible proportion of lean dry weight in clupeids (Shul'man 1974) and ash content is seasonally consistent in alewives and other clupeids (Thompson 1966; Travis 1966). Protein appeared to be an energy source during gonad maturation. The decrease in lean dry body weight during gonad maturation was possibly the result of amino acid transfer from the body to the gonad (Love 1970) and of differential use of amino acids for lipid metabolism (Brett and Groves 1979). Dietary energy sources most likely supplemented the protein and stored lipid that were mobilized for maintenance during inshore migration, gonad growth, and spawning activity in the spring. Several other temperate teleosts undergo rapid spring gonad maturation (Burns 1976; Wootton 1979) and this probably also requires high rates of food consumption (Wootton 1979). Resumption of feeding in the early spring would benefit those individuals that had started the winter with insufficient lipid stores.

Fishes that fast during the spawning season suffer sizeable losses of body energy, and the incidence of repeat spawners is often correlated with the degree of somatic depletion. Glebe and Leggett (1981) separated iteroparous species from semelparous species based on somatic energy loss during spawning. Those species above $60 \%$ somatic energy loss (for example, chinook salmon, $85 \%$, and Florida populations of American shad, $70 \%$ ) were semelparous whereas those below $60 \%$ (Connecticut populations of American shad, 40$60 \%$, and Atlantic salmon Salmo salar, 55\%) were iteroparous. Spawning-related mortality for the iteroparous Connecticut American shad was close to $70 \%$. Somatic depletion of Lake Michigan alewives in the present study ranged from 32 to $49 \%$, which indicates that spawning is a critical period for this population. It is much more critical if one adds in depletion during the winter ( 27 to $37 \%$ ), which is not experienced by the species listed above due to their ocean residence. Return spawners along coastal Maine have been reported for alewife populations in which spawning-related mortalities reach 40 to $60 \%$ (Havey 1961; Kissel 1974). Brown (1968) reported an average yearly mortality of $68 \%$ for Lake Michigan alewives during the 1960 s, a period of low predator pressure and large die-offs. It is probable that a high proportion of that mortality was related to overwintering and spawning stress in conjunction with insufficient lipid storage in the fall. 
A major assumption involved in this growth analysis is that size at capture reflects actual growth, i.e., size-selective sampling or mortality did not occur. Smaller individuals with lower energy reserves may succumb to overwinter and spawning stress more readily than larger fish of comparable age (Oliver et al. 1979; Adams et al. 1982). However, there is no evidence that the length composition of dead alewives sampled during the die-off in July 1967 differed substantially from the live alewives trawled at the same time (Brown 1968). All mortality of alewives is not due to spring die-offs, however; predation probably causes most mortality now (Stewart et al. 1981). Size-selective predation could alter the size composition of alewives sampled, but the nature of this alteration is unknown.

The increases in length, weight, and body calories of age- 0 alewives during their first winter were unlike those of all other fish analyzed in this study. The total length of age- 0 fish in October was consistent with that reported by Brown (1972) for alewives during the 1960s and by Jude et al. (1981) for young of year during the latter 1970s. However, the size of these fish may not have represented the entire population of age- 0 alewives in southeastern Lake Michigan. Differential movement of larger individuals may have made only one size group available to sampling gear. Alternatively, different collecting gear (trawls in the fall, gillnets in the spring) may have introduced a sampling bias. The only data that appear inconsistent in the study are for overwinter growth of young of year; growth of immature fish during their first winter could be overestimated, and may actually reflect a faster fall growth and slower, or negative, overwinter growth.

Mortality has been documented for several fish species in relation to declines in energy reserves over long winters (Oliver et al. 1979) and to cold temperatures (McLean et al. 1980). There is some evidence of direct lethal effects of winter temperature on alewife populations (Colby 1973), although insufficient energy stores, possibly due to intraspecific competition, are most commonly believed to cause alewife die-offs in Lake Michigan (Brown 1972). This belief is supported partially in this study, because body lipid and lean dry body weight were at seasonal lows in the spring for each age group. However, the relationship between total lipid or lean dry weight and death by starvation has not been defined for alewives, so one cannot conclude that the low levels observed here are the direct cause of mortality.

There is an inverse relationship in many fish between lipid and water content (Shul'man 1974). This relationship is particularly strong in our results. Loss of stored body lipids resulted in increased water content of the body and wet weight was conserved. Therefore, an examination of wet weight fluctuations in alewives is not useful in analyzing energy content of the population. Percent lipid is an excellent indicator of body energy content in alewives, lean dry weight and total lipid are of intermediate value, and wet weight is a poor predictor. These results are similar to work on clupeids and other fishes that store fat (Shul'man 1974; Foltz and Norden 1977; Pierce et al. 1980), but differ substantially from data for lean fishes (e.g., northern pike, Diana and Mackay 1979; and largemouth bass Micropterus salmoides Adams et al. 1982). In lean fish (body lipid content less than $5 \%$ ), wet weight is usually a good indicator of total energy content.

\section{Acknowledgments}

L. Wells and R. Owens of the U.S. Fish and Wildlife Service were instrumental in obtaining alewives from offshore waters. D. Jude provided necessary equipment for collecting fish from inshore waters. J. Dorr, C. Madenjian, G. Noguchi, D. Ottey, P. Schneeberger, and many others assisted in data collection and interpretation. This publication is a result of work sponsored by the Michigan Sea Grant College Program, under grant NA-80AA-D-0072, project R/GLF-17, from the National Oceanic and Atmospheric Administration, U.S. Department of Commerce, and by funds from the State of Michigan. This is Contribution 397 of the Great Lakes Research Division, University of Michigan.

\section{References}

Adams, S. M., R. B. McLean, AND M. M. Huffman. 1982. Structuring of a predator population through temperature-mediated effects on prey availability. Canadian Journal of Fisheries and Aquatic Sciences 39:1175-1184.

Brett, J. R., AND T. D. D. Groves. 1979. Physiological energetics. Pages 279-352 in W. S. Hoar, D. J. Randall, and J. R. Brett, editors. Fish Physiology, volume VIII. Academic Press, New York, NY, USA.

Brown, E. H., JR. 1968. Population characteristics and physical condition of alewives in a massive 
die-off in Lake Michigan, 1967. Great Lakes Fishery Commission, Ann Arbor, MI, USA.

Brown, E. H., JR. 1972. Population biology of alewives in Lake Michigan, 1949-1970. Journal of the Fisheries Research Board of Canada 29:477500.

BURNS, J. R. 1976. The reproductive cycle and its environmental control in the pumpkinseed, $L e$ pomis gibbosus. Copeia 1976:449-455.

Colby, P. J. 1973. Response of the alewives to environmental change. U.S. Fish and Wildlife Service, Great Lakes Fishery Laboratory Contribution 472, Ann Arbor, MI, USA.

COOPER, R. A. 1961. Early life history and spawning migration of the alewife, Alosa pseudoharengus. Master's thesis. University of Rhode Island, Kingston, RI, USA.

CRAIG, J. F. 1977. Body composition of adult perch (Perca fluviatilis) in Windermere, with reference to seasonal changes and reproduction. Journal of Animal Ecology 46:617-632.

DiANA, J. S., AND W. C. MACKAY. 1979. Timing and magnitude of energy deposition and loss in the body, liver, and gonads of northern pike ( $E s o x$ lucius). Journal of the Fisheries Research Board of Canada 36:481-487.

Folch, J., M. Lees, and G. H. S. Stanley. 1957. A simple method for the isolation and purification of total lipids from animal tissue. Journal of $\mathrm{Bi}$ ological Chemistry 226:497-509.

Foltz, J. W., AND C. R. NoRden. 1977. Seasonal changes in food consumption and energy content of smelt in Lake Michigan. Transactions of the American Fisheries Society 106:230-234.

Fox, D. J., AND K. E. GuIRE. 1976. Documentation for MIDAS. University of Michigan, Statistical Research Laboratory, Ann Arbor, MI, USA.

Glebe, B. D., AND W. C. LegGetT. 1981. Latitudinal variations in energy allocation and use during the freshwater migrations of American shad (Alosa sapidissima) and their life history consequences. Canadian Journal of Fisheries and Aquatic Sciences 38:806-820.

GrahaM, J. J. 1956. Observations on the alewife, Pomolobus pseudoharengus (Wilson), in fresh water. Publication of the Ontario Fisheries Research Laboratory 74, Toronto, Canada.

HAvEY, K. A. 1961. Restoration of anadromous alewives at Long Pond, Maine. Transactions of the American Fisheries Society 90:281-286.

ILES, T. D. 1974. The tactics and strategy of growth in fishes. Pages 331-345 in F. R. Harden Jones, editor. Sea fisheries research. Elek Scientific, London, England.

JUdE, D. J., AND EIGHT COAUTHors. 1981. Adult, juvenile and larval fish populations in the vicinity of the J. H. Campbell power plant, eastern Lake Michigan, 1977-1980. University of Michigan, Great Lakes Research Division Special Report 86, Ann Arbor, MI, USA.

Kaitaranta, J. K., AND R. G. Ackman. 1981. Total lipid and lipid classes of fish roe. Comparative Biochemistry and Physiology B, Comparative Biochemistry 69:725-729.

Kissell, G. W. 1974. Spawning of the anadromous alewife in Bride Lake, Connecticut. Transactions of the American Fisheries Society 103:312-317.

LASKER, R. 1962. Efficiency and rate of yolk utilization by developing embryos and larvae of the Pacific sardine Sardinops caerulea (Girard). Journal of the Fisheries Research Board of Canada 19: 867-875.

Love, R. M. 1970. The chemical biology of fishes. Academic Press, New York, NY, USA.

McLean, R. B., P. T. Singley, J. S. GRIfFITh, AND M. V. MCGEE. 1980. Threadfin shad impingement: effect of cold stress. Oak Ridge National Laboratory, Oak Ridge, TN, USA.

Miller, R. G. 1966. Simultaneous statistical inference. McGraw-Hill, New York, NY, USA.

Oliver, J. D., G. F. Holeton, And K. E. ChuA. 1979. Overwinter mortality of fingerling smallmouth bass in relation to size, relative energy stores, and environmental temperature. Transactions of the American Fisheries Society 108:130-136.

PAINE, R. T. 1971. The measurement and application of the calorie to ecological problems. Annual Review of Ecology and Systematics 2:145-164.

Pierce, R. J., T. E. Wissing, J. G. JAworski, R. N. Givens, AND B. A. Megrey. 1980. Energy storage and utilization patterns of gizzard shad in Acton Lake, Ohio. Transactions of the American Fisheries Society 109:611-616.

Pritchard, A. L. 1929. The alewife (Pomolobus pseudoharengus) in Lake Ontario. Publication of the Ontario Fisheries Research Lab 38:37-54, Toronto, Canada.

RothschiLd, B. J. 1963. A critique of the scale method for determining the age of the alewife, Alosa pseudoharengus (Wilson). Transactions of the American Fisheries Society 92:409-413.

Shul'man, G. E. 1974. Life cycles of fish; physiology and biochemistry. John Wiley and Sons, New York, NY, USA.

SMITH, S. E. 1968. Species succession and fishery exploitation in the Great Lakes. Journal of the Fisheries Research Board of Canada 25:667-693.

Stewart, D. J., J. F. Kitchell, ANd L. B. Crowder. 1981. Forage fishes and their salmonid predators in Lake Michigan. Transactions of the American Fisheries Society 110:751-763.

Thompson, M. H. 1966. Proximate composition of Gulf of Mexico industrial fish. Fishery Industrial Research 3:29-50.

Travis, D. R. 1966. Proximate composition of Lake Michigan alewife. Fishery Industrial Research 3: $1-4$.

Wilkins, N. P. 1967. Starvation of the herring, Clupea harengus L.: survival and some gross biochemical changes. Comparative Biochemistry and Physiology 23:503-518.

Williams, G. C. 1966. Adaptation and natural se- 
lection. Princeton University Press, Princeton, NJ, USA.

WoodHeAd, A. D. 1979. Senescence in fishes. Symposium of the Zoological Society of London 44: 179-205.

WoOtTON, R. J. 1979. Energy costs of egg production and environmental determinants of fecundity in teleost fishes. Symposium of the Zoological Society of London 44:133-159.

YEO, S. E. 1978. Seasonal variation in food consumption and caloric content of the alewife, Alosa pseudoharengus (Wilson), in Lake Michigan. Master's thesis. University of Wisconsin, Milwaukee, WI, USA. 